\title{
The need for deepened molecular mechanism exploration in new onset diabetes after transplantation (NODAT)
}

\author{
Ke Zhang ${ }^{1}$, Shusen Zheng $^{1,2}$ \\ ${ }^{1}$ Division of Hepatobiliary and Pancreatic Surgery, Department of Surgery, The First Affiliated Hospital, School of Medicine, Zhejiang University, \\ Hangzhou, China; ${ }^{2}$ Department of Hepatobiliary and Pancreatic Surgery, Department of Liver Transplantation, Shulan (Hangzhou) Hospital, \\ Zhejiang Shuren University School of Medicine, Hangzhou, China \\ Correspondence to: Prof. Shusen Zheng. Division of Hepatobiliary and Pancreatic Surgery, Department of Surgery, The First Affiliated Hospital, \\ School of Medicine, Zhejiang University, Hangzhou, China; Department of Hepatobiliary and Pancreatic Surgery, Department of Liver \\ Transplantation, Shulan (Hangzhou) Hospital, Zhejiang Shuren University School of Medicine, Hangzhou, China. Email: shusenzheng@zju.edu.cn. \\ Comment on: Man Kim J, Hwang S, Lee KW, et al. New-onset diabetes after adult liver transplantation in the Korean Organ Transplantation Registry \\ (KOTRY) study. Hepatobiliary Surg Nutr 2020;9:425-39.
}

Submitted Oct 01, 2021. Accepted for publication Oct 21, 2021.

doi: $10.21037 / \mathrm{hbsn}-2021-22$

View this article at: https://dx.doi.org/10.21037/hbsn-2021-22

New onset diabetes after transplantation (NODAT) has begun to receive attention from transplant surgeons in recent years. NODAT is a common metabolic complication that occurs after liver transplantation (LT), with a reported incidence ranging from $9-63.3 \%$ in recipients who are previously nondiabetic (1). The development of NODAT has been associated with an increased risk of cardiovascular disease, infection, chronic renal insufficiency, and graft dysfunction after LT, and leads to increased long-term mortality in liver recipients (2-7). The study by Man Kim et al. (8) was the first to investigate the incidence and risk factors of NODAT in Korean LT patients and was completed with the Korean Organ Transplantation Registry (KOTRY) database. Nearly $70 \%$ of LTs recorded in the KOTRY are living donor LTs (LDLTs); the incidence and the risk factors of NODAT in the KOTRY are not entirely consistent with those reported in studies based on deceased donor LT (DDLT) $(2,9,10)$.

The study (8) indicated that in addition to increasing recipient age, high recipient BMI, steroid use, and left-sided LT being risk factors for NODAT, small-size liver graft (GRWR $\leq 0.8$ ) or minimally invasive donor hepatectomy, including laparoscopic donor hepatectomy or robotic donor hepatectomy, was an independent risk factor of NODAT for LDLT. However, the exact mechanism underlying this association is not clear, and the authors believe it may be related to liver inflammation.
Currently, the study on the mechanism of occurrence of NODAT has been receiving increasing attention from researchers, and thus far interleukin 6 (IL-6) has been associated with the occurrence of NODAT (11). High mobility group box 1 protein (HMGB1), as a marker of hepatocellular injury in LT, is considered to have a possible association with insulin resistance after LT (11), and studies on HMGB1-related pathways may provide novel and practicable ideas for the prevention and treatment of NODAT. More research is needed to determine the connection between liver inflammation and ischemiareperfusion injury after LT and the occurrence and development of NODAT.

As mentioned above, there are limitations to this study. First, the KOTRY database does not include actual laboratory findings and intraoperative data, such as operative time, cold and hot ischemic time, and other relevant information, which may also be closely related to the development of NODAT after LT. In addition, the immunosuppression protocols and the management of NODAT is important. It has been shown that maintenance immunosuppression with tacrolimus and steroids is a risk factor for NODAT (12-15). The study did not provide data on tacrolimus blood levels and steroid use after LT. Second, the study had a relatively short follow-up period, with a median follow-up time of 1 year. However, the majority $(90 \%)$ of NODAT cases in the study developed NODAT 
within 6 months after LT, and those who developed NODAT at a later time might have been influenced by other factors, such as lifestyle habits of diet, smoking, or physical activity, as well as the development of other comorbidities like hyperlipidemia and hypertension. Further studies with longer follow-up periods are still needed to assess the long-term impact of NODAT on the outcomes in LT patients.

In the meantime, we call for more researchers to focus on NODAT after LT. NODAT may be closely associated with long-term recipient survival, and it is crucial to explore its mechanism and relevant variable factors for improving the long-term outcome of LT patients.

\section{Acknowledgments}

We acknowledge the contributions of Man Kim et al. in this study, whose work provided the Korean data for relevant studies and helped clarify the differences between Western and Asian countries.

Funding: None.

\section{Footnote}

Provenance and Peer Review: This article was commissioned by the editorial office, Hepatobiliary Surgery and Nutrition. The article did not undergo external peer review.

Conflicts of Interest: Both authors have completed the ICMJE uniform disclosure form (available at https://hbsn. amegroups.com/article/view/10.21037/hbsn-2021-22/coif). The authors have no conflicts of interest to declare.

Ethical Statement: The authors are accountable for all aspects of the work in ensuring that questions related to the accuracy or integrity of any part of the work are appropriately investigated and resolved.

Open Access Statement: This is an Open Access article distributed in accordance with the Creative Commons Attribution-NonCommercial-NoDerivs 4.0 International License (CC BY-NC-ND 4.0), which permits the noncommercial replication and distribution of the article with the strict proviso that no changes or edits are made and the original work is properly cited (including links to both the formal publication through the relevant DOI and the license).
See: https://creativecommons.org/licenses/by-nc-nd/4.0/.

\section{References}

1. Li DW, Lu TF, Hua XW, et al. Risk factors for new onset diabetes mellitus after liver transplantation: A metaanalysis. World J Gastroenterol 2015;21:6329-40.

2. Moon JI, Barbeito R, Faradji RN, et al. Negative impact of new-onset diabetes mellitus on patient and graft survival after liver transplantation: Long-term follow up. Transplantation 2006;82:1625-8.

3. Lv C, Zhang $\mathrm{Y}$, Chen $\mathrm{X}$, et al. New-onset diabetes after liver transplantation and its impact on complications and patient survival. J Diabetes 2015;7:881-90.

4. Sarno G, Mehta RJ, Guardado-Mendoza R, et al. Newonset diabetes mellitus: predictive factors and impact on the outcome of patients undergoing liver transplantation. Curr Diabetes Rev 2013;9:78-85.

5. Yagi S, Kaido T, Iida T, et al. New-onset diabetes mellitus after living-donor liver transplantation: association with graft synthetic function. Surg Today 2017;47:733-42.

6. Parekh J, Corley DA, Feng S. Diabetes, hypertension and hyperlipidemia: prevalence over time and impact on longterm survival after liver transplantation. Am J Transplant 2012;12:2181-7.

7. Ling Q, Xu X, Xie H, et al. New-onset diabetes after liver transplantation: a national report from China Liver Transplant Registry. Liver Int 2016;36:705-12.

8. Man Kim J, Hwang S, Lee KW, et al. New-onset diabetes after adult liver transplantation in the Korean Organ Transplantation Registry (KOTRY) study. Hepatobiliary Surg Nutr 2020;9:425-39.

9. Wallia A, Illuri V, Molitch ME. Diabetes Care After Transplant: Definitions, Risk Factors, and Clinical Management. Med Clin North Am 2016;100:535-50.

10. Kuo HT, Sampaio MS, Ye X, et al. Risk factors for newonset diabetes mellitus in adult liver transplant recipients, an analysis of the Organ Procurement and Transplant Network/United Network for Organ Sharing database. Transplantation 2010;89:1134-40.

11. Sun J, He Y, Bai L, et al. An Analysis of the Risk Factors for New-Onset Diabetes Mellitus After Liver Transplantation. Int J Gen Med 2021;14:4783-92.

12. Kim YK, Lee KW, Kim SH, et al. Early steroid withdrawal regimen prevents new-onset diabetes mellitus in old-age recipients after living donor liver transplantation. World J 
Surg 2012;36:2443-8.

13. Sgourakis G, Radtke A, Fouzas I, et al. Corticosteroidfree immunosuppression in liver transplantation: a metaanalysis and meta-regression of outcomes. Transpl Int 2009;22:892-905.

14. Segev DL, Sozio SM, Shin EJ, et al. Steroid avoidance in liver transplantation: meta-analysis and meta-regression of randomized trials. Liver Transpl 2008;14:512-25.

15. Oufroukhi L, Kamar N, Muscari F, et al. Predictive factors for posttransplant diabetes mellitus within one-year of liver transplantation. Transplantation 2008;85:1436-42.

Cite this article as: Zhang $\mathrm{K}$, Zheng $\mathrm{S}$. The need for deepened molecular mechanism exploration in new onset diabetes after transplantation (NODAT). HepatoBiliary Surg Nutr 2021;10(6):896-898. doi: 10.21037/hbsn-2021-22 